\title{
Potencialna učinkovitost vedenjsko-kognitivne terapije pri obravnavi sorojencev otrok s posebnimi potrebami
}

\author{
Mojca Petrič \\ Pedagoška fakulteta, Univerza na Primorskem
}

\begin{abstract}
Povzetek: V prispevku predstavljamo izsledke empiričnih raziskav, ki so proučile psihosocialno delovanje sorojencev otrok s posebnimi potrebami (PP) ter podajamo smernice za obravnavo sorojencev po principih vedenjsko-kognitivne terapije (VKT). V splošnem se kaže, da se večina sorojencev uspešno prilagodi na odraščanje v družini, ki ima otroka s PP, se pa ti v primerjavi z normativnimi sorojenci srečujejo $\mathrm{z}$ dodatnimi izzivi in težavami, kot so večja mera prevzemanja odgovornosti v družini, težave $\mathrm{v}$ interakcijah z vrstniki in okolico. Pri nekaterih se tako razvijejo težave v psihosocialnem prilagajanju. Določeni programi za obravnavo sorojencev otrok s PP že obstajajo, vendar so, kot predstavljamo v prispevku, predvsem podporne narave, njihova učinkovitost pa je slabše empirično podprta. Glede na vsebino izzivov in težav, s katerimi se spoprijemajo sorojenci, tako predlagamo obravnavo po principih VKT ter konkretne tehnike za delo.
\end{abstract}

Ključne besede: sorojenci, posebne potrebe, psihosocialna prilagojenost, vedenjsko-kognitivna terapija

\section{The potential efficacy of cognitive-behavioral therapy in the treatment of siblings of children with special needs}

\author{
Faculty of Education, University of Primorska, Slovenia
}

\begin{abstract}
In this article, we present the empirical findings on psychosocial adjustment of siblings of children with special needs, as well as cognitive-behavioural therapy (CBT) and its techniques as a potential treatment choice. We conclude that most siblings adjust rather well to having a brother/sister with special needs. Still, they are dealing with more challenges and difficulties than siblings of children with typical development, such as having a role of a caregiver, or experiencing stigmatizing interactions with their peers or others, some also develop psychological and/or adjustment problems. There have been some sibling support programs, but little research has been conducted to address their efficacy, and the current findings are contradictory. Considering the challenges the siblings are facing, we believe CBT is a reasonable treatment option.
\end{abstract}

Keywords: siblings, special needs, psychosocial adjustment, cognitive-behavioural therapy

\footnotetext{
*Naslov/Address: Mojca Petrič, Pedagoška fakulteta, Univerza na Primorskem, Cankarjeva 5, 6000 Koper, e-pošta: mojca.petric@pef.upr.si 


\section{Duševno zdravje oz. psihosocialno prilagajanje sorojencev otrok $s$ posebnimi potrebami}

Sistemska družinska perspektiva družino opredeljuje kot sistem, v katerem posamezni dogodki oz. spremembe učinkujejo na vse njene člane. Kadar ima eden od otrok v družini posebne potrebe (v nadaljevanju PP), se vsi člani družine soočajo $\mathrm{z}$ dodatnimi izzivi in zahtevami v primerjavi z normativnimi družinami (Orsmond in Mailick, 2007; Rossiter in Sharpe, 2001). Raziskovalce je v začetku zanimal predvsem učinek, ki ga ima vzgoja otroka s PP na starše, predvsem mame. V splošnem so ugotovili, da mame izkusijo večjo mero stresa in depresivnih simptomov kot mame normativnih otrok, vendar pa se lahko uspešno prilagodijo na spremembe in izzive (Dykens, 2005). Kasneje je večje število raziskovalcev svoje zanimanje preusmerilo na proučevanje psihosocialne prilagojenosti oz. duševnega zdravja sorojencev otrok s PP. Izsledki raziskav so še vedno nedosledni; medtem ko nekateri kažejo, da se sorojenci dobro prilagodijo ter se uspešno soočajo s situacijami, povezanimi z njihovim bratom ali sestro ter se v psihosocialnem delovanju ne razlikujejo od otrok, ki nimajo brata ali sestre s PP (Stoneman, 2005) oz. do večje mere razvijejo nekatere pozitivne lastnosti(npr. empatijo, potrpežljivost, samostojnost), drugi kažejo, da se pri njih pojavlja povečano tveganje za razvoj težav v psihosocialnem delovanju oz. duševnem zdravju (Tsamparli, Tsibidaki in Roussos, 2011). Nasprotujoče si ugotovitve so verjetno vsaj deloma posledica uporabljene metodologije, saj raziskovalci uporabljajo različne mere psihološke prilagojenosti, o težavah največkrat poročajo starši ali vzgojitelji/učitelji, zelo pogosto so $\mathrm{v}$ raziskave vključeni tako otroci kot mladostniki z različnimi posebnimi potrebami (Benson in Karlof, 2008).

Ob ugotovljenih nedoslednostih so določeni raziskovalci s pomočjo meta-analize ter splošnega pregleda literature s tega področja prišli do verjetno nekoliko bolj jasnih zaključkov. L. Rossiter in Sharpe (2001; Sharpe in Rossiter, 2002) sta izvedla dve meta-analitični študiji, pri čemer sta $\mathrm{v}$ prvi primerjala psihosocialno prilagajanje sorojencev otrok z motnjo v duševnem razvoju in sorojencev, katerih brat/sestra nima PP, v drugi pa psihosocialno prilagajanje sorojencev $\mathrm{s}$ kroničnimi boleznimi in njihove vrstnike, ki nimajo brata/sestre s PP. Izsledki raziskav so pokazali, da imajo sorojenci otrok s PP nekoliko več psihičnih težav (predvsem z depresivnostjo in anksioznostjo) kot primerjalna skupina, vendar pa so bili ti učinki majhni (in nepomembni) za sorojence otrok $\mathrm{z}$ motnjo $\mathrm{v}$ duševnem razvoju ter zmerni za sorojence otrok s kroničnimi boleznimi. V zadnjih letih so se raziskovalci $v$ večji meri osredotočili na proučevanje duševnega zdravja sorojencev otrok z motnjo avtističnega spektra. Orsmond in Mailick-Seltzer (2007) sta opravila pregled izsledkov raziskav s tega področja. Ugotovila sta, da ni mogoče izpeljati doslednih zaključkov. V splošnem kaže, da sorojenci otrok $\mathrm{z}$ motnjo avtističnega spektra $\mathrm{v}$ primerjavi s sorojenci, ki nimajo brata/sestre s PP, podobno pozitivno zaznavajo sebe in lastno kompetentnost, kaže pa se trend $\mathrm{k}$ večji meri težav ponotranjenja (npr. anksioznost, depresivnost) in pozunanjenja (vedenjske težave), te pa pri večini niso tako velike, da bi zadostovale kriterijem za klinično diagnozo. Tveganje za razvoj težav v psihosocialnem prilagajanju se poveča $\mathrm{v}$ mladostništvu. $\mathrm{V}$ raziskavi, ki sta jo avtorja kasneje izvedla na mladostnikih, teh ugotovitev nista podprla (Orsmond in Mailick Seltzer, 2009); bratje oseb s PP so poročali o manjši meri depresivnih simptomov kot bratje, ki nimajo sorojenca s PP, sestre oseb s PP pa o približno enaki meri kot tiste, ki nimajo sorojenca s PP. Prav tako med sorojenci oseb s PP in primerjalno skupino nista ugotovila razlik v izraženosti simptomov anksioznosti. Omeniti velja tudi izsledke ene od novejših študij (Giallo, GavidiaPaine, Minett in Kapoor, 2012), ki je temeljila na samooceni duševnega zdravja otrok in mladostnikov, ki imajo sorojenca s PP (z različnimi diagnozami, npr. motnjo avtističnega spektra, motnjo v duševnem razvoju, cerebralno paralizo). Večina sorojencev je poročala o dobrem duševnem zdravju na vseh področjih, kar pomeni, da niso presegali kritične meje, ki bi kazala na težave v duševnem zdravju, pa vendar so poročali o več čustvenih in vedenjskih težavah ter težavah s pozornostjo kot normativni sorojenci. Pri približno 20 do 30 \% udeležencev so ugotovili povečano tveganje za razvoj težav v duševnem zdravju oz. so bile težave že prisotne.

Redki raziskovalci so proučili dejavnike, s katerimi bi lahko pojasnili povečano tveganje za razvoj težav v psihosocialnem delovanju pri nekaterih sorojencih otrok s PP. Statične spremenljivke, kot so spol, ujemanje spola sorojencev, starost sorojencev, vrstni red rojstva sorojencev ipd. nimajo pomembnega učinka (Hastings, 2007). Kaže, da so eden od pomembnih dejavnikov vedenjske težave otrok s PP, in sicer močnejše kot so, več težav v psihosocialnem delovanju imajo njihovi bratje ali sestre (Hastings, 2007; Neece, Blacher in Baker, 2010). Pri sorojencih otrok $\mathrm{z}$ avtizmom so dodatno ugotovili, da je uspešnost njihovega psihosocialnega delovanja pomembno povezana $\mathrm{z}$ vključenostjo staršev $\mathrm{v}$ ustrezne izobraževalne programe za avtizem, konkretno v program ABA (angl. applied behavior analysis). Možno je, da tako starši lažje obvladujejo vedenjske težave otrok $\mathrm{z}$ avtizmom, $\mathrm{s}$ tem pa upade tudi starševski stres in število konfliktov $\mathrm{v}$ družini. Poveča se lahko tudi starševa samoučinkovitost, kar lahko vodi so izboljšanja odnosa med starši in vsemi otroki $\mathrm{v}$ družini. Za uspešno psihosocialno prilagajanje sorojencev je pomembna tudi pozitivna družinska klima in nižje število stresnih dogodkov (Benson in Karlof, 2008).

Poleg poznavanja dejavnikov, povezanih s psihosocialno prilagojenostjo sorojencev, je potrebno poznati tudi vsebino konkretnih izkušenj in izzivov, s katerimi se ti srečujejo. J. Barr in S. McLeod (2010) sta analizirali prispevke otrok in mladostnikov, ki so opisali svoje izkušnje odraščanja $\mathrm{z}$ bratom ali sestro s PP na spletni strani nacionalne avstralske organizacije za osebe s PP. Ugotovili sta, da se v njihovem vsakdanjem življenju pojavljajo predvsem tri tematike, podobne teme pa so se pojavljale tudi v slovenski raziskavi o sorojencih otrok s PP (Sagadin, 2015):

- Interakcija z nepoznanimi ljudmi: sorojenci so poročali o tem, da se včasih v situacijah, ko drugi strmijo v njihovega brata ali sestro ali podajo neustrezne komentarje, počutijo neprijetno. Prav tako jih je sram, kadar brat/sestra z neprimernim ali izstopajočim vedenjem na javnih mestih (npr. v nakupovalnem središču) pritegne pozornost nase oz. na celotno družino. 
- Interakcija $z$ vrstniki: nekateri otroci in mladostniki so izpostavili, da jih vrstniki ne razumejo in da se počutijo drugačne. J. Barr in S. McLeod (2010) v prispevku navajata izjavo enega od sorojencev: »Zdi se, da nihče ne razume, kako je biti v moji situaciji. Vključno s sošolci in starši. Neprijetno si je zamisliti, da ni nikogar, ki bi vedel, kako se počutiš v neki situaciji, ki je povezana s sorojencem s PP« (str. 167). Drugi sorojenci so poudarili skrb glede obiskov njihovih prijateljev na domu ter vzpostavljanja interakcij z njihovimi brati in sestrami. Ob neprimernih izjavah, ki se nanašajo na osebe s PP ali specifično na njihovega sorojenca, lahko doživijo čustva jeze in razočaranja. Nekateri so poročali tudi o zasmehovanju in nesprejemanju njihovih bratov in sester, zaradi česar so izkusili močne stiske.

- Družinska interakcija: sorojenci so opisovali, da imajo njihovi starši manj časa zanje, da prejmejo manjšo mero pozornosti, večkrat so na prvem mestu potrebe otroka s PP, potrebno je več organizacije za družinske dejavnosti, te so lahko prekinjene, zaradi česar so večkrat žalostni ali jezni. Poročali so tudi o tem, da prevzemajo več odgovornosti v družini kot njihovi sovrstniki, da jih skrbi, ali staršem nudijo zadostno mero pomoči, nekateri čutijo krivdo, ker zaznavajo, da te ni dovolj. Določeni so poročali o tem, da se težko spopadajo z zaznavo negativnih čustev pri starših.

Sorojenci otrok s PP se lahko srečujejo tudi z drugimi težavami in izzivi (Meyer in Vadasy, 2008; Sagadin, 2015; Seligman in Darling, 2007):

- Lahko jih skrbi, da bi tudi sami zboleli oz. razvili motnjo $\mathrm{v}$ prihodnosti. Ta strah se $\mathrm{z}$ večjo verjetnostjo pojavi pri tistih, ki imajo sorojenca $\mathrm{z}$ duševno motnjo, pri tistih, katerih sorojenci so npr. zboleli za rakom, imajo epilepsijo, okvare vida in sluha. Na povečanje tovrstnega strahu vpliva tudi pomanjkanje ustreznih informacij o vzroku primanjkljajev oz. motnje. Dodatne težave, vezane na omenjeni strah, so povečana pozornost na manjše znake, ki lahko kažejo na bolezen, motnjo oz. okvaro, glavoboli, težave s spanjem ter druge psihosomatske težave. Nekateri se srečujejo tudi s strahom pred smrtjo brata ali sestre $\mathrm{s}$ PP, strahom pred poškodbo ali operacijo brata oz. sestre.

- Pojavljajo se lahko občutki krivde, ker sami nimajo PP, nekateri krivijo sebe za bolezen oz. primanjkljaj svojih sorojencev, krivda se pojavi tudi ob tipičnih konfliktih, ki se pojavljajo med sorojenci, saj lahko zaznavajo, da jih ne smejo zbadati ali se jeziti nanje.

- Kot negativne izkušnje nekateri navajajo moteče vedenje brata/sestre, kot je kričanje, škripanje z zobmi, agresivno vedenje, usmerjeno nanje.

- Razvijejo lahko težnjo po doseganju visokih rezultatov (na šolskem/ športnem/ glasbenem področju) in perfekcionizem. Čeprav so nekateri strokovnjaki predvidevali, da pritisk po dosežkih izhaja iz staršev, so kasneje ugotovili, da lahko težnja po kompenzaciji za sorojenčeve PP izvira iz njih samih.

Ob pregledu izsledkov empiričnih znanstvenih raziskav ter strokovne literature bi lahko zaključili, da se večina sorojencev sicer uspešno prilagodi na odraščanje $\mathrm{v}$ družini $\mathrm{z}$ bratom ali sestro s PP, še vedno pa se sorojenci srečujejo $\mathrm{z}$ določenimi specifičnostmi, zaradi katerih se lahko pojavijo težave $\mathrm{v}$ psihosocialnem prilagajanju. Nekateri otroci in mladostniki že imajo izražene duševne motnje, zato je smiselno oblikovati ustrezen način obravnave za različne skupine sorojencev otrok s PP.

\section{Trenutni programi za sorojence otrok $s$ posebnimi potrebami}

Organizacije in/ali posamezni strokovnjaki, ki obravnavajo osebe s PP in njihove družinske člane, so prepoznali potrebe sorojencev oseb s PP in tako oblikovali njim namenjene programe, ki pa so predvsem preventivne in podporne narave. Večinoma potekajo v obliki skupinskih delavnic, namenjeni pa so nudenju informacij (vključno s psihoedukacijo) ter čustvene in socialne opore (Gettings, Franco in Paramala, 2015). Med najbolj znanimi je program Sibshops, ki ga je oblikoval Don Meyer (Meyer in Vadasy, 2008). V Sloveniji npr. programe za otroke in odrasle sorojence oseb $\mathrm{z}$ motnjo $\mathrm{v}$ duševnem razvoju izvaja zveza Sožitje. Nekatere organizacije nudijo informacije in individualno psihološko podporo tudi prek spleta, npr. organizacija Sibs iz Velike Britanije (Sibs: For brothers and sisters of disabled children and adults, n.d.), skupinske delavnice prek spleta pa potekajo tudi v obliki avdiokonferenc (Gettings idr., 2015).

Le redko so avtorji programov oz. njihovi izvajalci te programe tudi evalvirali. Organizacija Siblings Australia (2007) z uporabo psiholoških vprašalnikov ni ugotovila razlik $\mathrm{v}$ samoocenah psihološke prilagojenosti sorojencev pred in po udeležbi v skupini za sorojence, so pa ugotovili, da so tako sorojenci kot starši poročali o subjektivnih napredkih. Gettings in sodelavci (2015) so evalvirali učinek udeležbe v skupini za sorojence, ki je potekala v obliki avdiokonference prek spleta. Oblikovali so skupino šestih sorojencev, starih med 8 in 13 let, katerih bratje oz. sestre so imeli diagnozo motnje avtističnega spektra $z$ (več) pridruženimi motnjami, kot so motnje pozornosti in hiperaktivnost, obsesivnokompulzivna motnja in motnja $\mathrm{v}$ duševnem razvoju. Delo je potekalo $\mathrm{v}$ obliki edukacije (razumevanje motnje oz. primanjkljaja brata ali sestre), diskusij na temo šole, prostega časa, pričakovanj in želja za prihodnost ter reševanja težav drugih otrok, ki imajo sorojenca s PP. S kvalitativno analizo odgovorov sorojencev so ugotovili, da se je po izvedbi delavnic izboljšala komunikacija med njimi in ostalimi družinskimi člani, imeli so manj skrbi, vezanih na sorojence s PP. Izboljšanja pri normativnih sorojencih so pripisali ustreznemu razumevanju PP brata/sestre, novim načinom spoprijemanja $\mathrm{z}$ neprilagojenim vedenjem otroka s PP, bolj doslednemu odzivanju staršev v primeru agresivnega vedenja otroka s PP, ki je bilo usmerjeno nanje, ter pogovoru s starši o težavah, ki se pojavljajo v odnosu med sorojencema. Starševske ocene psihološkega delovanja svojih otrok na vprašalnikih so bile pred intervenco nižje kot po intervenci, kar ni pričakovano. Avtorji so na podlagi dodatnih komentarjev, ki so jih podali starši, sklepali, da so se po izvedbi skupinskih delavnic starši $\mathrm{v}$ večji meri zavedali otrokovega delovanja ter tako podali bolj realistične ocene. A. M. Dailey (2013) je evalvirala 
učinek delavnic Sibshops za sorojence. Kvalitativna analiza odgovorov staršev je pokazala, da delavnice dosegajo ključne cilje, ki so jih zastavili avtorji programa, tj. pridobivanje ustreznih informacij o motnji oz. primanjkljaju brata ali sestre, delitev izkušenj $\mathrm{z}$ drugimi sorojenci, medsebojno učenje reševanja problemov, preživljanje časa $\mathrm{z}$ otroki in mladostniki, ki imajo podobne izkušnje (kar prispeva $\mathrm{k}$ zmanjšanju zaznave osamljenosti), ter izobraževanje staršev o izzivih, s katerimi se srečujejo njihovi normativni otroci.

Če povzamemo, so ugotovitve evalvacijskih raziskav dokaj nedosledne. Kvalitativni odgovori sicer nakazujejo na pozitivne učinke za različna področja psihosocialnega delovanja sorojencev, medtem ko kvantitativni podatki teh ugotovitev ne podpirajo. Predvidevamo, da bi nekateri sorojenci, sploh tisti, ki se že srečujejo s težavami v duševnem zdravju, potrebovali individualno oz. bolj intenzivno in sistematično skupinsko obravnavo. Glede na vsebino izzivov in težav, s katerimi se soočajo, bi predlagali obravnavo po principih vedenjsko-kognitivne terapije (VKT).

\section{Potencialna vloga vedenjsko-kognitivne terapije (VKT) pri obravnavi sorojencev otrok s PP}

Vedenjsko-kognitivna terapija in iz nje izhajajoči modeli obravnave so bili $\mathrm{v}$ zadnjih desetletjih intenzivno raziskovani, tako na področju modelov konceptualizacije posameznih težav ali motenj kot tudi učinkovitosti terapije pri različno starih posameznikih, vključno $\mathrm{z}$ otroki in mladostniki (npr. Butler, Chapman, Forman in Beck, 2006; Hofmann, Asnaani, Vonk, Sawyer in Fang, 2012). Pregledna študija metaaanalitičnih raziskav Hoffmana in sodelavcev zelo zanesljivo kaže, da je učinkovitost VKT pri otrocih in mladostnikih empirično dobro podprta za raznolika področja težav ali motenj, od razpoloženjskih, anksioznih in somatoformnih na enem delu ter vedenjskih motenj in delinkventnosti na drugem delu spektra. Podobno kažejo izsledki nekaterih drugih metaanalitičnih raziskav o učinkovitosti VKT pri specifičnih težavah in motnjah. L. D. Seligman in Ollendick (2011) sta analizirala 40 študij, ki so proučile učinkovitost VKT pri otrocih in mladostnikih z anksioznimi motnjami ali težavami. Ugotovila sta, da lahko za dva od treh obravnavanih otrok pričakujemo, da bosta po treh do štirih mesecih redne tedenske obravnave dosegla pomembno izboljšanje v doživljanju anksioznosti, kar pomeni, da ob koncu terapije ne bosta dosegala kriterijev klinične motnje, učinki terapije pa bodo dolgotrajni. C. David-Ferdon in N. J. Kaslow (2008) sta analizirali rezultate raziskav, ki so proučile učinek posameznih oblik terapij oz. intervenc pri otrocih z razpoloženjskimi težavami ali motnjami. Ugotovili sta, da k upadu depresivnih simptomov tako pri klinični kot pri neklinični populaciji otrok in mladostnikov v največji meri prispevajo tiste, ki temeljijo na principih VKT. Sukhodolsky, Kassinove in Gorman (2004) so v metaanalitični raziskavi podprli učinek VKT tehnik pri delu z jezo in agresivnostjo pri otrocih in mladostnikih. Poudarjajo, da so določene tehnike (npr. učenje socialnih spretnosti) učinkovitejše pri zmanjšanju agresivnega vedenja, druge pa pri znižanju intenzitete jeze (npr. reševanje problemov).
V nobeni od omenjenih študij niso specifično obravnavali posebnosti sorojencev otrok s PP, prav tako nobena od študij ni proučila, ali življenje z bratom oz. sestro s PP pomembno vpliva na sam izraz težav ter na učinkovitost pomoči. Glede na izzive in težave, s katerimi se sorojenci soočajo, predvidevamo, da lahko VKT oz. posamezne tehnike pomembno prispevajo $\mathrm{k}$ boljšemu psihosocialnemu delovanju sorojencev. Tako v nadaljevanju predstavljamo te tehnike in nekatere izsledke raziskav, ki kažejo na učinkovitost VKT tehnik pri otrocih in mladostnikih s podobnimi težavami, a drugačno etiologijo.

Vedenjsko-kognitivni model temelji na predpostavki, da so otrokova oz. mladostnikova čustva in vedenje odvisna od načina, kako ti zaznavajo in interpretirajo določene dogodke oz. situacije (Kendall, 2012). Če upoštevamo poročanja sorojencev o njihovih razlagah določenih situacij, ki se nanašajo na brata oz. sestro, so te pogosto vir neprijetnih čustev. Kot smo že opisali, sorojenci otrok s PP npr. pogosto čutijo krivdo ob konfliktu s sorojencem. Ta krivda načeloma izvira iz informacij, ki jih prejemajo od odraslih: »Pusti ga na miru. Si večji, si pametnejši, ti bodi tisti, ki bo popustil.« (Meyer in Vadasy, 2008, str. 15). Otrok ali mladostnik verjetno te informacije ponotranji, zato se ob sledečih konfliktih aktivira negativni notranji samogovor, ta pa sproži čustvo krivde, ki se pri normativnih sorojencih načeloma ne pojavi. Podobno velja za ostale specifične situacije, s katerimi se soočajo. Kot osnovno metodo pri delu s sorojenci bi torej izpostavili prepoznavo čustev in samogovora (oz. negativnih avtomatskih misli) ter razumevanja kognitivnega modela, tj. odnosa med samogovorom, čustvi, telesnim odzivom in vedenjem, kot ključno metodo pa kognitivno restrukturacijo misli. Tehnike za prepoznavanje čustev otrokom oz. mladostnikom omogočajo, da se naučijo razlikovati med različnimi čustvenimi stanji ter boljše razumejo povezave med situacijami, mislimi in čustvi (Bailey, 2001). Prepoznavanje čustev z mlajšimi otroki lahko izvedemo v obliki različnih iger, kot je npr. metanje kocke, na kateri so narisani obrazi z različnimi čustvi. Otrok nato čustva povezuje s specifičnimi situacijami. Pomembno je tudi, da otrok prepozna in poimenuje telesne spremembe, ki se pojavljajo ob čustvih (Seiler, 2008). Zavedanje telesnega vzburjenja je še posebej pomembno pri obvladovanju jeze, to pa lahko sorojenci doživljajo v več okoliščinah, ki se navezujejo na brata ali sestro s PP (npr. ob neustreznih reakcijah drugih ljudi na osebe s PP, ob neustreznem vedenju sorojenca do njih samih). Ob zavedanju vzburjenja in jeze jih lahko kasneje učimo veščin za vzpostavljanje samonadzora, npr. inhibicijskih samonavodil (»Stop!« »Premisli!« »Kakšne možnosti imam?«; Rotvejn Pajič, 2001, str. 85) ter drugih tehnik, ki so se pokazale kot učinkovite pri nadzoru jeze, npr. predvidevanja posledic določenega vedenja (Sukhodolsky idr., 2004).

Za prepoznavo samogovora oz. negativnih avtomatskih misli je pomembno samoopazovanje teh misli (Seligman in Ollendick, 2011). Pri otrocih ter nekaterih mladostnikih lahko najprej izhajamo iz primerov drugih otrok in konkretnih ponazoritev (npr. narišemo oblačke, v katere zapišemo misli), nato pa jih usmerjamo $\mathrm{k}$ prepoznavi lastnih misli in razumevanju kognitivnega modela na lastnem primeru (Seiler, 2008). Na ta način odkrijemo kognitivne distorzije in v nadaljevanju otroka oz. mladostnika učimo kognitivne restrukturacije misli (Seligman in Ollendick, 2011), ki poteka 
v obliki vodenih vprašanj, kot so »Kako misliš, da bi to situacijo videl tvoj prijatelj?«, »Kaj pa bi on naredil?« (Bailey, 2001, str. 272). Zaradi predhodnih negativnih izkušenj, ki so se nanašale na posmehovanje oseb s PP, se lahko npr. pri sorojencu, ko pride $\mathrm{z}$ bratom na igrišče, pojavi negativni notranji govor v obliki: »Gotovo se smejijo mojemu bratu. Itak pa mi je vseeno. Greva stran.« Z vprašanji kot so: »Ali obstaja kakšna druga razlaga za to, da se otroci smejijo?« otroka oz. mladostnika vodimo k oblikovanju nadomestnega prepričanja. Podobno velja za ostale negativne avtomatske ali iracionalne misli, ki so pogoste pri sorojencih, npr. »Nihče ne ve, kako je biti v moji situaciji« (Barr in McLeod, 2010, str. 167), »Zakaj se to ni zgodilo meni (Meyer in Vadasy, 2008, str. 14)?«. Ena od pomembnih tehnik za preverjanje veljavnosti negativnih avtomatskih misli so vedenjski eksperimenti (Seligman in Ollendick, 2011). Kot smo že navedli, se sorojencem pogosto pojavljajo tudi vprašanja $\mathrm{v}$ zvezi z obiski vrstnikov na domu (Barr in McLeod, 2010). Tako bi lahko v primeru negativnih avtomatskih misli v oblikah »Sošolec me ne bo želel obiskati, če bo doma tudi moj brat«, »Kaj, če me sošolec ne bo želel obiskati?«, otrok oz. mladostnik svoje predpostavke preveril tako, da bi sošolca dejansko vprašal, če bi ga obiskal. Pred tem je potrebna tudi ustrezna priprava sorojenca na morebitni negativni odgovor s strani vrstnika. Vedenjski eksperimenti so primerni tudi v primeru, kadar sorojenci izražajo težnjo $\mathrm{k}$ perfekcionizmu (Center for Clinical Interventions, n.d.).

Ob večji meri stresorjev, s katerimi se soočajo sorojenci oseb s PP, so pomembne tudi tehnike sproščanja (Rotvejn Pajič, 2001). Že otroke lahko s pomočjo konkretnega materiala naučimo globokega dihanja in progresivne mišične relaksacije, ki jim lahko pomaga $\mathrm{v}$ primeru anksioznosti ali težav z obvladovanjem jeze. Zaradi konkretnih problemov, s katerimi se srečujejo sorojenci, npr. z obvladovanjem vedenjskih težav brata/sestre s PP, neustreznih reakcij drugih ljudi na njihove brate/sestre, je potrebno predstaviti tudi tehniko reševanja problemov. Ta tehnika predstavlja pomemben del že obstoječih programov za sorojence, vendar pa nismo zasledili, da bi udeležence sistematično učili korakov, ki vodijo do sprejemanja ustreznih odločitev. Eden od načinov dela, ki bi bil po našem mnenju primeren za individualno delo s sorojenci, je tehnika SPEAR, ki poteka v pet korakih (Nelson III, Finch Jr. in Cash Ghee, 2012): v prvem koraku otrok/mladostnik identificira problem, nato poišče vse možne rešitve, oceni, katera je najbolj primerna, to rešitev preizkusi v konkretni situaciji in oceni, ali je delovala. V primeru, če bi otrok npr. poročal, da ima težave z opravljanjem domače naloge, saj ga brat/sestra ves čas moti, ko teka po sobi, lahko uporabimo to tehniko. $\mathrm{V}$ obravnavo lahko vključimo tudi trening asertivnosti. Tehnika je primerna $\mathrm{v}$ primerih, ko otrok oz. mladostnik zaznava, da ne zmore izraziti svojega mnenja. Z usvajanjem veščin asertivnosti se lahko otroci in mladostniki npr. ustrezno spoprimejo s situacijami, v katerih bi se želeli zavzeti za svojega sorojenca oz. osebe s PP nasploh, pa tega ne naredijo, kar jim pogosto predstavlja frustracijo. Tudi izsledki raziskav so pokazali, da je trening asertivnosti učinkovita intervenca $\mathrm{v}$ primeru izogibalnih vedenj ter anksioznosti pri otrocih in mladostnikih (PracticeWise, n. d.). Pri tistih sorojencih, ki se srečujejo s prekomerno skrbjo za sorojenca ali z depresivnimi simptomi, je verjetno smiselno vpeljati večjo mero zabavnih in prijetnih dejavnosti. Vedenjska aktivacija ter udeležba $\mathrm{v}$ prijetnih dejavnostih namreč predstavlja pomembno intervenco pri mladostnikih z depresivno simptomatiko (Bailey, 2001). Pri sorojencih otrok s PP je v tem primeru pomembno tudi sodelovanje staršev. Ena od večjih organizacij, namenjenih sorojencem oseb s PP (Sibs, n. d.), starše nagovarja, naj sorojencu omogočijo, da vsaj do določene mere sam odloča, koliko časa bo preživel s svojim bratom ali sestro, naj ga spodbujajo k udejstvovanju $\mathrm{v}$ prijetnih dejavnostih ter da mu omogočijo, da ne prevzeme prevelike odgovornosti za skrb otroka s PP.

Opisali smo le VKT tehnike, ki so potencialno uporabne za obravnavo specifičnih težav, s katerimi se lahko srečujejo sorojenci otrok s PP. Menimo, da jih lahko uporabimo tako $\mathrm{v}$ preventivne namene $\mathrm{v}$ obliki skupinske obravnave, kot tudi za individualno obravnavo ob tveganjih za razvoj težav v duševnem zdravju oz. ko so se te že pojavile. V slednjem primeru so pomembne tudi vse ostale VKT tehnike, ki jih uporabljamo pri obravnavi otrok in mladostnikov.

\section{Literatura}

Bailey, V. (2001). Cognitive-behavioral therapies for children and adolescents. Advances in Psychiatric Treatment, 7, 224-232.

Barr, J. in McLeod, S. (2010). They never see how hard it is to be me: Siblings' observations of strangers, peers and family. International Journal of Speech-Language Pathology, 12(2), 162-171.

Benson, P. R. in Karlof, K. L. (2008). Child, parent, and family predictors of latter adjustment in siblings of children with autism. Research in Autism Spectrum Disorders, 2, 583-600.

Butler, A. C., Chapman, J. E., Forman, E. M. in Beck, A. T. (2006). The empirical status of cognitive-behavioral therapy: A review of meta-analyses. Clinical Psychology Review, 26, 17-31.

Center for Clinical Interventions. (n. d.). Module 5: Reducing my perfectionism behaviours. Pridobljeno s strani http://www.cci.health.wa.gov.au/docs/ 5\%20Reducing\%20my\%20Perfectionist $\% 20$ Behaviour. pdf

Dailey, A. M. (2013). Sibshops: How effective are they in helping siblings (magistrsko delo). Pridobljeno s strani http://sophia.stkate.edu/msw_papers/165

David-Ferdon, C. in Kaslow, N. J. (2008). Evidence-based psychosocial treatments for child and adolescent depression. Journal of Clinical Child \& Adolescent Psychology, 37(1), 62-104.

Dykens, E. M. (2005). Happiness, well-being, and character strengths: Outcomes for families and siblings of persons with mental retardation. Mental Retardation, 43(5), 360-364.

Gettings, S., Franco, F. in Paramala, J. (2015). Facilitating support groups for siblings of children with neurodevelopmental disorders using audio-conferencing: A longitudinal feasibility study. Child and Adolescent Psychiatry and Mental Health, 9(1), 1-15.

Giallo, R., Gavidia-Paine, S., Minett, B. in Kapoor, A. (2012). Sibling voices: The self-reported mental health of siblings of children with a disability. Clinical Psychologist, 16(1), 36-43. 
Hastings, R. P. (2007). Longitudinal relationships between sibling behavioral adjustment and behavior problems of children with developmental disabilities. Journal of Autism and Developmental Disorders, 37, 1485-1492.

Hofmann, S. G., Asnanni, A., Vonk, I. J., Sawyer, A. T. in Fang, A. (2012). The efficacy of cognitive behavioral therapy: A review of meta-analyses. Cognitive Therapy and Research, 36(5), 427-440.

Kendall, P. C. (2012). Guiding theory for therapy with children and adolescents. V P. C. Kendall (ur.), Child and adolescent therapy (2. izd., str. 3-26). New York, NY, ZDA: The Guilford Press.

Meyer, D. J. in Vadasy, P. F. (2008). Sibshops: Workshops for siblings of children with special needs, revised edition. Baltimore, MA, ZDA: Brooks.

Neece, C. L., Blacher, J. in Baker, B. L. (2010). Impact on siblings of children with intellectual disability: The role of child behavior problems. American Journal on Intellectual and Developmental Disabilities, 115(4), 291-306.

Nelson III, W. M., Finch Jr., A. J. in Cash Ghee, A. (2012). Anger management with children and adolescents. V P. C. Kendall (ur.), Child and adolescent therapy: Cognitivebehavioral procedures (4. izd., str. 92-143). New York, NY, ZDA: Guilford Press.

Orsmond, G. I. in Mailick Seltzer. M. (2007). Siblings of individuals with autism spectrum disorders across the life course. Mental Retardation and Developmental Disabilities: Research Reviews, 13, 313-320.

Orsmond, G. I. in Mailick Seltzer, M. (2009). Adolescent siblings of individuals with an autism spectrum disorder: Testing a deathesis-stress model of sibling well-being. Journal of Autism and Developmental Disorders, 39, 1053-1065.

PracticeWise. (n.d.). Evidence-based child and adolescent psychosocial interventions. Pridobljeno s strani https:// www.practicewise.com/

Rossiter, L. in Sharpe, D. (2001). The siblings of individuals with mental retardation: A quantitative integration of the literature. Journal of Child and Family Studies, 10(1), 65-84.
Rotvejn Pajič, L. (2001). Kombiniranje tehnik v vedenjski in kognitivni terapiji. Psihološka obzorja, 10(1), 81-90.

Sagadin, N. (2015). Položaj in potrebe sorojencev, ki imajo brata ali sestro s posebnimi potrebami (neobjavljeno magistrsko delo). Pedagoška fakulteta Univerze v Ljubljani, Slovenija.

Seiler, L. (2008). Cool connections with cognitive behavioral therapy: Encouraging self-esteem, resilience and wellbeing in children andyoung people using CBT approaches. London, Združeno kraljestvo: Jessica Kingsley.

Seligman, L. D. in Ollendick, T. H. (2011). Cognitive behavioral therapy for anxiety disorders in youth. Child \& Adolescent Psychiatric Clinics of North America, 20(2), 217-238.

Seligman, M. in Darling, R. B. (2007). Ordinary families, special children: A systems approach to childhood disability (3. izd.). New York, NY, ZDA: Guilford Press.

Sharpe, D. in Rossiter, L. (2002). Siblings of children with a chronic illness: A meta-analysis. Journal of Pediatric Psychology, 2(8), 699-710.

Siblings Australia. (2007). Sibworks: A quantitative analysis of a program for siblings of children with special needs. Canberra, Avstralija: Siblings Australia Inc. \& Commonwealth Department of Health and Aging.

Sibs: For brothers and sisters of disabled children and adults. (n.d.). Pridobljeno s strani http://www.sibs.org.uk/

Stoneman, Z. (2005). Siblings of children with disabilities: Research themes. Mental Retardation, 43, 339-350.

Sukhodolsky, D. G., Kassinove, H. in Gorman, B. S. (2004). Cognitive-behavioral therapy for anger in children and adolescents: A meta-analysis. Aggression and Violent Behavior, 9(3), 247-269.

Tsamparli, A., Tsibidaki, A. in Roussos, P. (2011). Siblings in Greek families: Raising a child with disabilities. Scandinavian Journal of Disability Research, 13(1), $1-19$.

Weisz, J. R., McCarty, C. A., \& Valerie, S. M. (2006). Effects of psychotherapy for depression in children and adolescents: A meta-analysis. Psychological Bulletin, 132(1), 132-149. 